\title{
THE IMPACT OF MACROECONOMIC INDICATORS ON THE BUSINESS PERFORMANCE OF FINANCIAL INSTITUTIONS IN THE REPUBLIC OF SERBIA: PANEL DATA ANALYSIS
}

\author{
Željko Račič \\ Novi Sad School of Business, Novi Sad, Republic of Serbia \\ Dajana Ercegovac \\ Novi Sad School of Business, Novi Sad, Republic of Serbia \\ Dragana Milić \\ Novi Sad School of Business, Novi Sad, Republic of Serbia
}

\begin{abstract}
This paper aims to estimate the impact of macroeconomic indicators (gross domestic product - GDP, inflation rate and industrial production index) on liquidity, profitability and solvency of financial institutions in the Republic of Serbia. The research is based on applying a dynamic GMM panel model, while the results of the application of static panel models were analyzed as the control results. The research results support the assumption that the growth of GDP and inflation rates affects the increase of financial institutions' profitability. Also, the estimation results implicate that the growth of GDP and the inflation rate is linked with the reduction of financial institutions' liquidity, while the growth of industrial production rate affects its increase. Finally, the results of the study indicate that GDP growth has an influence on the rise of financial sector solvency. This comparative analysis using panel data models is relevant to a broad range of researchers and policymakers interested in macroeconomic relations and the financial sector.
\end{abstract}

Keywords: macroeconomic indicators, financial institutions performance, static panel data models, dynamic panel data models

JEL classification: E6, G21, G22

\footnotetext{
*raciczeljko@gmail.com
} 


\title{
PANEL ANALIZA UTICAJA MAKROEKONOMSKIH POKAZATELJA NA POSLOVANJE FINANSIJSKIH INSTITUCIJA U REPUBLICI SRBIJI
}

\begin{abstract}
Sažetak: Cilj ovog rada je da pruži ocenu uticaja makroekonomskih indikatora (bruto domaćeg proizvoda - BDP, stope inflacije $i$ indeksa industrijske proizvodnje) na likvidnost, profitabilnost $i$ solventnost finansijskih institucija $u$ Republici Srbiji. Istraživanje je bazirano na primeni dinamičkog GMM panel modela, dok su kao kontrolni rezultati analizirani rezultati primene statičkih panel modela. Rezultati istraživanja idu u prilog pretpostavke da rast bruto domaćeg proizvoda i stopa inflacije utiču na povećanje profitabilnosti finansijskih institucija. Takođe, rezultati ukazuju da rast bruto domaćeg proizvoda $i$ stopa inflacije utiču na smanjenje likvidnosti finansijskih institucija, dok rast stope industrijske proizvodnje utiče na njeno povećanje. $\mathrm{Na}$ kraju, rezultati istraživanja impliciraju da rast BDP utiče na rast solventnosti finansijskog sektora. Komparativna studija primenom panel modela je relevantna širokom krugu istraživača $i$ kreatorima ekonomske politike, zainteresovanim za makroekonomske relacije i finansijski sektor.
\end{abstract}

Ključne reči: makroekonomski pokazatelji, performanse finansijskih instituticija, statički panel modeli, dinamički panel modeli

\section{INTRODUCTION}

Macroeconomic indicators determine stability and encourage economic growth and development in each country. The business results of financial institutions, as intermediaries that connect demand and supply in the financial markets, significantly depend on the movement of leading economic indicators. This paper aims to assess the impact of macroeconomic developments on the efficiency of financial institutions in the Republic of Serbia. The panel data analysis was performed on a sample of 23 financial institutions, of which 20 banks and three insurance companies. The research covers the period from 2017 to 2020 .

We conduct the assessment of macroeconomic trends based on GDP growth rate, inflation rate and the index of industrial production in the Republic of Serbia. The research results are based on applying a dynamic GMM panel model, followed by the analysis of control results of the application of static panel models. The research data is the financial statements of analyzed domestic financial companies. The research aims to evaluate the characteristics of statistically significant nexus between the macroeconomic indicators and liquidity, profitability and capital level of financial institutions. The paper's 
35 | The impact of macroeconomic indicators on the business performance of financial institutions in the Republic of Serbia: Panel data analysis

conclusions can be helpful for policymakers and macroeconomic and business analysts interested in economic movements in the national financial sector.

\section{BRIEF LITERATURE REVIEW}

The domestic financial sector has gone through huge and turbulent changes in the last twenty years. The entry of foreign capital, acquisitions and stronger prudential control induced necessary transformation in order to establish a more efficient and profitable financial sector (Ercegovac, Vlaović Begović, \& Jovin, 2019). The mentioned research concludes that there is a trend of concentration of the total profits and losses in the domestic banking sector, significant capital adequacy, substantial liquidity with the dominant share of foreign banks in total assets, equity, and realized profits of the banking sector. On the other hand, with the high level of liquidity and capital adequacy ratio, Milišić and Račić (2019) conclude that domestic banks face an excess of credit potential and rising nonperforming loans with the significant market concentration and a dominant share of the five largest banks in the banking sector. Moreover, foreign banks also lead ahead in the implementation of innovations and digitizing the customer services and banking procedures (Ercegovac, Jovin, \& Račić, 2018).

The analysis of the impact of macroeconomic trends on financial institutions (Mitrović, Nestorović, \& Ljubić, 2016) is mainly based on the empirical analysis (Lucchetta, 2007; Bohachova, 2008; Trenca, Petria \& Corovei, 2015; Kiymaz, 2004; Swamy, 2012; Somoye \& Ilo, 2009) and the use of various forms of regression analysis (Newbold, Carlson \& Thorne, 2010). In previous researches, GDP and inflation rates, as main macroeconomic indicators, are analyzed the most often. On the other side, liquidity, profitability and capital adequacy are analyzed as business characteristics of the financial institutions.

The theoretical framework supports the view that GDP growth, as the most important macroeconomic variable, has a positive impact on the operations of financial institutions, primarily because of rising interest rates and increasing the creditworthiness of market entities (Račić, Stanišić \& Račić, 2014). Previous research on the role of macroeconomic indicators on banks during the last global economic crisis (Hamid, Waheed \& Khalid, 2014), then in the Republic of China (Sufian \& Habibullah, 2009), as well as in comparative studies of their impact on business within traditional and Islamic banking (Mohammad, Asutay, Dixon \& Platonova, 2020), backed up the assumption that GDP growth has a positive impact on the banking sector. Živkov, Poparić and Ilić (2020) come to the conclusion that GDP level and inflation rate affect only long-term loans to enterprises. However, there are studies that come to the opposite results, such as a study of banks in India (Al-Homaidi, Almaqtari, 
Yahya \& Amgad, 2020), with the conclusion that GDP growth and inflation affect the reduction of bank profitability.

Previous research shows that inflation was a statistically significant variable but with mixed effects on liquidity (Hamid, Waheed \& Khalid, 2014; Račić, 2014) and bank profitability (Sufian \& Habibullah, 2009; Hada, Bărbuță-Mișu, Cristina Iuga \& Wainberg, 2020; Živkov, Poparić \& Ilić, 2020; Olufemi \& Muazu, 2020). Also, inflation has a weakly positive correlation, statistical significance, with liquidity indicators of banking LTD (loan to deposit ratio) (Milić, 2017).

Finally, previous researches indicate a positive correlation between the growth of industrial outputs and the increase of business results of financial institutions. Research supports the assumption that financial institutions perform better in countries with a higher level of international trade (Olufemi \& Muaza, 2020) and countries with a higher share of foreign investment in overall investments (Hamid, Waheed \& Khalid, 2014).

\section{DATA AND METHODOLOGY}

\subsection{SAMPLE}

The research is based on a sample of twenty banks that cover $85 \%$ of the total assets of the domestic banking sector and three insurance companies that cover $48 \%$ of the total assets of the insurance sector of Serbia. The list of banks and insurance companies is presented in the following table (Table 1).

The sample includes only financial institutions with complete data set for the entire period covered by the research. The research is based on the analysis of quarterly financial reports, a total of 460 observations. 
37 | The impact of macroeconomic indicators on the business performance of financial institutions in the Republic of Serbia: Panel data analysis

Table 1

Financial institutions in the sample

\begin{tabular}{lll}
\hline $\mathbf{N}$ & The name of financial institution & Type \\
\hline 1. & API Bank a.d. Beograd & bank \\
2. & Addiko Bank a.d. Beograd & bank \\
3. & AIK Bank a.d. Beograd & bank \\
4. & Banca Intesa a.d. Beograd & bank \\
5. & Banka Poštanska štedionica a.d. Beograd & bank \\
6. & Crédit Agricole Bank Serbia a.d. Novi Sad & bank \\
7. & Direktna banka a.d. Kragujevac & bank \\
8. & Erste Bank a.d. Novi Sad & bank \\
9. & Eurobank a.d. Beograd & bank \\
10. & Expobank a.d. Beograd & bank \\
11. & Halkbank a.d. Beograd & bank \\
12. JUBMES Bank a.d. Beograd & bank \\
13. & Komercijalna banka a.d. Beograd & bank \\
14. & MTS Bank a.d. Beograd & bank \\
15. & NLB Bank a.d. Beograd & bank \\
16. & Opportunity Bank a.d. Novi Sad & bank \\
17. & ProCredit Bank a.d. Beograd & bank \\
18. & Raiffeisen Bank a.d. Beograd & bank \\
19. & Sberbank Serbia a.d. Beograd & bank \\
20. & Société Générale Bank Serbia a.d. Beograd & insurance \\
\hline 21. & DDOR & \\
22. & Generali & insance \\
23. & Dunav & \\
\hline & & Rence \\
\hline
\end{tabular}

Note. Retrieved from National Bank of Serbia, www.nbs.rs 


\subsection{METHODOLOGY}

To obtain reliable estimates of regression coefficients, we based the conclusions on the application of the dynamic regression model GMM - General Method of Moments (Arelano \& Bond, 1991, Kripfganz, 2021, Bond, 2002). This model is suitable for analyzing variables correlated with their values from previous periods and within models in which endogeneity is suspected. Endogeneity occurs if a significant independent variable is omitted in the model, which is more or less correlated with any of the model included variables. Furthermore, frequently the error of the model is not random but is correlated with some of the variables from the model. It is essential to point out that the probability of the presence of endogeneity is exceptionally high in regression models, making the application of the GMM model relevant for this research.

The control results of the research are based on the application of static panel regression models (Ahn \& Schmidt, 1995), which combine comparative data and time-series data. The static panel models are Pooled Effects model, Fixed Effects model and Random Effects model. The results of the application of these models differ from each other. Therefore, choosing the model that gives the statistically most significant estimates of regression coefficients is necessary. The selection of the relevant model is made based on the tests shown in the following table (Table2).

Table 2

Model selection tests within static panel regression models

\begin{tabular}{|lc|}
\hline Model selection & Test \\
\hline Pooled model vs. Fixed Effects model & F - Test \\
Pooled model vs. Random Effects model & Breusch - Pagan Test \\
Fixed Effects model vs. Random Effects model & Hausman Test \\
\hline
\end{tabular}

Note. Newbold, P., Carlson, W. L., \& Thorne, B. (2010). Statistika za poslovanje $i$ ekonomiju. Zagreb: MATE.

Within the research, we analyzed the following regression model:

$$
\left(l_{1} \text { roe, cap }\right)_{i j}=\beta_{0}+\beta_{1} g d p_{j}+\beta_{2} \text { inf } f_{j}+\beta_{3} \text { roe }+\beta_{4} \text { stopa_ind }_{j}+\omega_{i j}
$$

The paper analyzes the effects of macroeconomic indicators on the operations of financial institutions. As business indicators, we analyzed the following indicators of liquidity, profitability and solvency of financial institutions:

- $\boldsymbol{l}_{\boldsymbol{I}^{-}}$cash and cash equivalents to total assets ratio,

- roe - net profit to capital ratio, 
39 | The impact of macroeconomic indicators on the business performance of financial institutions in the Republic of Serbia: Panel data analysis

- $\quad$ cap - share of capital in the balance sheet total of banks and insurance companies.

The independent variables of the regression model are the following indicators:

- $\boldsymbol{g} \boldsymbol{d} \boldsymbol{p}$ - quarterly changes in the gross domestic product rate (nonseasonally adjusted data, changes compared to the same quarter of the previous year),

- inf - quarterly changes in the inflation rate (changes in consumer prices),

- rate_ind - quarterly changes in the rate of the index of industrial production in the Republic of Serbia.

The estimation of regression coefficients is based on the quarterly data analysis, covering the period from the second quarter of 2015 to the first quarter of 2020.

\section{PANEL DATA RESULTS}

\subsection{THE IMPACT OF MACROECONOMIC INDICATORS ON LIQUIDITY OF THE FINANCIAL INSTITUTIONS}

Results of the research (Table 3 and Table 4) confirmed that there are several statistically significant interdependencies between macroeconomic variables and liquidity of the financial institutions.

The static panel models estimated variations of the independent variables explain $17.6 \%$ of the L1 coefficient variations. Furthermore, the Hausman test confirmed that the Fixed - Effects model gives the most unbiased estimates of the regression coefficients.

After eliminating the heteroscedasticity and autocorrelation in the model, we emphasize that the growth of GDP and increase of inflation affect the reduction of liquidity of the financial institutions. Also, the estimates of regression coefficients support the conclusion that the growth rate of industrial production in the Republic of Serbia impacts the rise of the liquidity of the financial institutions. 
Table 3

Results of static panel regression models $\left(l_{1}\right)$

\begin{tabular}{|c|c|c|c|c|c|c|}
\hline \multirow{2}{*}{$l_{1}$} & \multicolumn{2}{|c|}{$\begin{array}{l}\text { Pooled (OLS) } \\
\text { model }\end{array}$} & \multicolumn{2}{|c|}{$\begin{array}{l}\text { Fixed - Effects } \\
\text { model }\end{array}$} & \multicolumn{2}{|c|}{$\begin{array}{c}\text { Random - Effects } \\
\text { model }\end{array}$} \\
\hline & Coef. & $\begin{array}{l}\text { Std. } \\
\text { Err. }\end{array}$ & Coef. & $\begin{array}{l}\text { Std. } \\
\text { Err. }\end{array}$ & Coef. & $\begin{array}{l}\text { Std. } \\
\text { Err. }\end{array}$ \\
\hline gdp & $-1.010^{* * * *}$ & 0.151 & $-1.009^{* * * *}$ & 0.212 & $-0.009^{* * * *}$ & 0.120 \\
\hline inf & $-0.946 * * *$ & 0.252 & $-0.948^{* * *}$ & 0.231 & $-0.948^{-* * *}$ & 0.200 \\
\hline rate_ind & $0.015^{* * * *}$ & 0.004 & $0.014^{* * * *}$ & 0.003 & $0.015^{* * * *}$ & 0.003 \\
\hline _cons & $0.195^{* * *}$ & 0.008 & $0.195^{* * * *}$ & 0.009 & $0.195^{* * *}$ & 0.009 \\
\hline $\begin{array}{l}\text { Coefficient of } \\
\text { determination }\end{array}$ & \multicolumn{2}{|c|}{$\begin{array}{c}\mathbf{R}^{2}=0.108 \\
\quad \text { (adjust) }\end{array}$} & \multicolumn{2}{|c|}{$\begin{array}{c}\mathbf{R}^{2}=0.176 \\
\text { (within) }\end{array}$} & \multicolumn{2}{|c|}{$\begin{array}{l}\mathbf{R}^{2}=0.176 \\
\text { (within) }\end{array}$} \\
\hline Model selection & \multicolumn{6}{|c|}{$\begin{array}{l}\text { Hausman test: } \\
\text { Prob }>\text { chi } 2=0.04=>\text { FE model is the most relevant }\end{array}$} \\
\hline $\begin{array}{l}\text { Elimination of } \\
\text { heteroscedasticity } \\
\text { and autocorrelation }\end{array}$ & \multicolumn{2}{|l|}{ - } & \multicolumn{2}{|c|}{ Robust. Std. Err. } & \multicolumn{2}{|l|}{ - } \\
\hline
\end{tabular}

$P$-values: * significant at $10 \%, * *$ significant at $5 \%, * * *$ significant at $1 \%$

Note. Calculation of authors using Stata 13 software.

Table 4

Results of dynamic regression model GMM - General Method of Moments $\left(l_{1}\right)$

\begin{tabular}{|c|c|c|}
\hline \multirow{2}{*}{$l_{1}$} & \multicolumn{2}{|c|}{ GMM - General Method of Moments } \\
\hline & Coef. & Std. Err. \\
\hline $\begin{array}{l}l_{1}(\operatorname{lag} 1) \\
\text { gdp } \\
\text { inf } \\
\text { rate_ind } \\
\text { _cons }\end{array}$ & $\begin{array}{c}-0.029 \\
\mathbf{- 0 . 4 9 6} \\
-0.209 \\
-0.00004 \\
\mathbf{0 . 1 6 5 * * *} \\
\end{array}$ & $\begin{array}{l}0.078 \\
0.272 \\
0.438 \\
0.003 \\
0.022 \\
\end{array}$ \\
\hline $\begin{array}{l}\text { Elimination of } \\
\text { heteroscedasticity and } \\
\text { autocorrelation }\end{array}$ & Robust. Std. Err. & \\
\hline
\end{tabular}

Note. Calculation of authors using Stata 13 software. 
41 | The impact of macroeconomic indicators on the business performance of financial institutions in the Republic of Serbia: Panel data analysis

Regarding the application of the GMM model, which gives the best estimates of the observed interdependencies, we concluded that only the growth of the GDP in the Republic of Serbia at a statistically significant level affects the reduction of national financial sector liquidity. The obtained estimates of regression coefficients using GMM model are shown in Table 4.

\subsection{THE IMPACT OF MACROECONOMIC INDICATORS ON PROFITABILITY OF THE FINANCIAL INSTITUTIONS}

Results of the research (Table 5 and Table 6) confirmed that there are several statistically significant interdependencies between macroeconomic variables and profitability of the domestic financial institutions.

The application of static panel regression models estimates that $9.7 \%$ of the variations in the profitability of domestic financial institutions are explained by the regressors included in the model. Based on the results of the Hausman test, we point out that the Random - Effects model gives the best estimations of the observed interdependencies.

Table 5

Results of static panel regression models (roe)

\begin{tabular}{|c|c|c|c|c|c|c|}
\hline \multirow{2}{*}{ roe } & \multicolumn{2}{|c|}{$\begin{array}{l}\text { Pooled (OLS) } \\
\text { model }\end{array}$} & \multicolumn{2}{|c|}{$\begin{array}{l}\text { Fixed - Effects } \\
\text { model }\end{array}$} & \multicolumn{2}{|c|}{$\begin{array}{c}\text { Random - } \\
\text { Effects model }\end{array}$} \\
\hline & Coef. & $\begin{array}{l}\text { Std. } \\
\text { Err. }\end{array}$ & Coef. & $\begin{array}{l}\text { Std. } \\
\text { Err. }\end{array}$ & Coef. & $\begin{array}{l}\text { Std. } \\
\text { Err. }\end{array}$ \\
\hline gdp & $1.816^{* * * *}$ & 0.448 & $1.814^{* * * *}$ & 0.354 & $1.814^{* * * *}$ & 0.488 \\
\hline inf & $3.056^{* * *}$ & 0.749 & $3.058^{* * *}$ & 0.591 & $3.058^{* * *}$ & 1.010 \\
\hline rate_ind & $-0.022^{*}$ & 0.012 & $-0.022^{* *}$ & 0.010 & $-0.022^{* *}$ & 0.011 \\
\hline _cons & $-0.091^{* * * *}$ & 0.022 & $-0.091^{* * * *}$ & 0.018 & $-0.091^{* *}$ & 0.042 \\
\hline $\begin{array}{l}\text { Coefficient of } \\
\text { determination }\end{array}$ & \multicolumn{2}{|c|}{$\begin{array}{c}\mathbf{R}^{2}=0.054 \\
\quad \text { (adjust) }\end{array}$} & \multicolumn{2}{|c|}{$\begin{array}{c}\mathbf{R}^{2}=0.097 \\
\quad \text { (within) }\end{array}$} & \multicolumn{2}{|c|}{$\begin{array}{c}\mathbf{R}^{2}=0.097 \\
\text { (within) }\end{array}$} \\
\hline Model selection & \multicolumn{6}{|c|}{$\begin{array}{l}\text { Hausman test: } \\
\text { Prob }>\text { chi2 }=0.999 \Rightarrow \text { RE model is the most relevant }\end{array}$} \\
\hline $\begin{array}{l}\text { Elimination of } \\
\text { heteroscedasticity } \\
\text { and autocorrelation }\end{array}$ & \multicolumn{4}{|c|}{ - } & \multicolumn{2}{|c|}{ Robust. Std. Err. } \\
\hline
\end{tabular}

Note. Calculation of authors using Stata 13 software. 
After eliminating heteroscedasticity and autocorrelation in the model, we find that the growth of GDP and inflation has a positive effect on the profitability of the financial institutions, while the growth of industrial production rate reduces their profitability.

Table 6 shows the results of the application of the dynamic GMM panel model. On the base of the estimation results of GMM model we stress that only inflation rate at a statistically significant level impacts the reduction of financial institutions profitability.

Table 6

Results of dynamic regression model GMM - General Method of Moments (roe)

\begin{tabular}{|c|c|c|c|c|}
\hline \multirow[t]{2}{*}{ roe } & \multicolumn{2}{|c|}{$\begin{array}{c}\text { GMM model } \\
\text { (lag 1) }\end{array}$} & \multicolumn{2}{|c|}{$\begin{array}{c}\text { GMM model } \\
(\operatorname{lag} 2)\end{array}$} \\
\hline & Coef. & Std. Err. & Coef. & Std. Err. \\
\hline roe (lag 1) & $0.756^{* * * *}$ & 0.144 & -0.152 & 0.127 \\
\hline roe (lag 2) & - & - & $0.626^{* * *}$ & 0.178 \\
\hline gdp & 0.231 & 0.374 & -1.041 & 2.798 \\
\hline inf & $-3.123^{*}$ & 1.875 & $-6.334^{*}$ & 3.751 \\
\hline rate_ind & -0.008 & 0.006 & 0.025 & 0.016 \\
\hline _cons & 0.055 & 0.045 & 0.155 & 0.156 \\
\hline $\begin{array}{l}\text { Elimination of } \\
\text { heteroscedasticity and } \\
\text { autocorrelation }\end{array}$ & \multicolumn{2}{|c|}{ Robust. Std. Err. } & \multicolumn{2}{|c|}{ Robust. Std. Err. } \\
\hline
\end{tabular}

Note. Calculation of authors using Stata 13 software.

\subsection{THE IMPACT OF MACROECONOMIC INDICATORS ON SOLVENCY OF THE FINANCIAL INSTITUTIONS}

Finally, obtained results (Table 7 and 8) confirmed that there are several statistically significant interdependencies between macroeconomic variables and the solvency of the financial institutions.

The research results (Table 7) estimate that only $2.4 \%$ of the variation in the share of capital in the balance sheet total of domestic financial sector is explained by analyzed macroeconomic indicators. The Hausman test confirmed that the Random - Effects model best describes the impact of macroeconomic developments on the solvency of domestic financial institutions. We concluded that there are no statistically significant interdependencies between analyzed variables after eliminating the heteroscedasticity and autocorrelation in the model. 
43 | The impact of macroeconomic indicators on the business performance of financial institutions in the Republic of Serbia: Panel data analysis

Table 7

Results of static panel regression models (cap)

\begin{tabular}{|c|c|c|c|c|c|c|}
\hline \multirow{2}{*}{ cap } & \multicolumn{2}{|c|}{$\begin{array}{c}\text { Pooled (OLS) } \\
\text { model }\end{array}$} & \multicolumn{2}{|c|}{$\begin{array}{c}\text { Fixed- Effects } \\
\text { model }\end{array}$} & \multicolumn{2}{|c|}{$\begin{array}{c}\text { Random- Effects } \\
\text { model }\end{array}$} \\
\hline & Coef. & $\begin{array}{l}\text { Std. } \\
\text { Err. }\end{array}$ & Coef. & $\begin{array}{l}\text { Std. } \\
\text { Err. }\end{array}$ & Coef. & $\begin{array}{l}\text { Std. } \\
\text { Err. }\end{array}$ \\
\hline gdp & -0.328 & 0.206 & $0.33^{* * * *}$ & 0.104 & -0.33 & 0.306 \\
\hline inf & -0.234 & 0.345 & -0.232 & 0.173 & -0.232 & 0.302 \\
\hline rate_ind & -0.001 & 0.006 & 0.002 & 0.003 & 0.002 & 0.018 \\
\hline _cons & $0.211^{* * * *}$ & 0.010 & $-0.21^{* * *}$ & 0.005 & $0.211^{* * * *}$ & 0.018 \\
\hline $\begin{array}{l}\text { Coefficient of } \\
\text { determination }\end{array}$ & \multicolumn{2}{|c|}{$\begin{array}{c}\mathbf{R}^{2}=0.005 \\
\text { (adjust) }\end{array}$} & \multicolumn{2}{|c|}{$\begin{array}{c}\mathbf{R}^{2}=0.024 \\
\text { (within) }\end{array}$} & \multicolumn{2}{|c|}{$\begin{array}{c}\mathbf{R}^{2}=0.024 \\
\text { (within) }\end{array}$} \\
\hline Model selection & \multicolumn{6}{|c|}{$\begin{array}{l}\text { Hausman test: } \\
\text { Prob }>\text { chi } 2=0.999 \Rightarrow \text { RE model is the most relevant }\end{array}$} \\
\hline $\begin{array}{l}\text { Elimination of } \\
\text { heteroscedasticity } \\
\text { and autocorrelation }\end{array}$ & \multicolumn{4}{|c|}{ 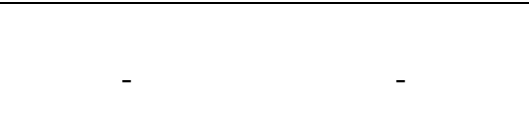 } & \multicolumn{2}{|c|}{ Robust. Std.Err. } \\
\hline
\end{tabular}

Note. Calculation of authors using Stata 13 software.

Table 8

Results of dynamic regression model GMM - General Method of Moments (cap)

\begin{tabular}{|c|c|c|c|c|}
\hline \multirow[t]{2}{*}{ cap } & \multicolumn{2}{|c|}{$\begin{array}{l}\text { GMM model } \\
\text { (lag 1) }\end{array}$} & \multicolumn{2}{|c|}{$\begin{array}{l}\text { GMM model } \\
\text { (lag 2) }\end{array}$} \\
\hline & Coef. & Std. Err. & Coef. & Std. Err. \\
\hline cap (lag 1) & 0.215 & 0.301 & $0.529^{*}$ & 0.278 \\
\hline cap (lag 2) & - & - & -0.293 & 0.262 \\
\hline gdp & 0.124 & 0.108 & $2.017^{* * *}$ & 0.777 \\
\hline inf & -0.170 & 0.343 & 1.657 & 1.041 \\
\hline rate_ind & -0.003 & 0.002 & -0.002 & 0.003 \\
\hline _cons & $0.153^{* *}$ & 0.065 & 0.054 & 0.064 \\
\hline $\begin{array}{l}\text { Elimination of } \\
\text { heteroscedasticity } \\
\text { and autocorrelation }\end{array}$ & \multicolumn{2}{|c|}{ Robust. Std. Err. } & \multicolumn{2}{|c|}{ Robust. Std. Err. } \\
\hline
\end{tabular}

P-values: * significant at $10 \%, * *$ significant at $5 \%, * * *$ significant at $1 \%$

Note. Calculation of authors using Stata 13 software. 
Finally, estimation results of the GMM model presented in Table 8 verifies that GDP growth at a statistically significant level affects the growth of solvency of financial institutions.

\section{CONCLUSION}

Based on the obtained research results, we concluded that the growth of GDP and inflation had an influence on the reduction of financial institutions liquidity, while the growth of the industrial production index affects its increase. Considering the expected existence of a negative correlation between profitability and liquidity, we find evidence that GDP growth and inflation (which in the observed period was within the framework that stimulates economic growth) impact the rise of financial sector profitability, i.e. reduce their liquidity. In conditions of economic growth, banks and insurance companies do not need to maintain a high level of secondary liquidity reserves, and it is easier for them to anticipate daily needs for liquid assets. Regarding the industrial production index, we can highlight that its growth has a positive effect on the financial situation in companies, which is reflected in the increase of their capacity to repay loans and purchase insurance policies. Moreover, the decrease in the share of non-performing loans and the increase in the volume of sales of insurance policies increase the liquidity of domestic financial institutions in general.

Furthermore, based on the empirical evidence, we can point out that the growth of GDP and inflation affect the increased profitability of financial institutions. The upward economic cycle increases the need for loans, which has a positive effect on banks' profitability. Also, in the conditions of economic expansion, with a rise in demand for loans, there is an increase in service expenses in the household sector, including insurance. Increased lending activity, accompanied BY low inflation rates that stimulate economic growth, increase banks and insurance company's profitability, which is in line with the survey results.

Finally, on the base of the presented results, we concluded that the growth of GDP increases the solvency of financial institutions. Despite the excellent capitalization of the domestic banking sector, the growth of GDP has further strengthened the stability of banks, which is a reasonable basis for the future development of the financial and real sector in the Republic of Serbia. This study is relevant to the vast number of researchers, analysts and policymakers interested in macroeconomic relations and the financial sector. Further research concerning the investigated nexus can be expanded with the use of data, including financial institutions in the Western Balkan countries. 
45 | The impact of macroeconomic indicators on the business performance of financial institutions in the Republic of Serbia: Panel data analysis

\section{REFERENCES}

Ahn, S., C., \& Schmidt, P. (1995). Efficient estimation of models for dynamic panel data. Journal of Econometrics, 68(1), 5-27.

Al-Homaidi, E. A., Almaqtari, F. A., Yahya, A. T., \& Amgad, S. D. (2020). Internal and external determinants of listed commercial banks' profitability in India: dynamic GMM approach. International Journal of Monetary Economics and Finance, 13(1), 34-67.

Arellano, M., \& Bond, S. (1991). Some Tests of Specification for Panel Data: Monte Carlo Evidence and an Application to Employment Equations. The Review of Economic Studies, 58(2), 277-297.

Bohachova, O. (2008). The impact of macroeconomic factors on risks in the banking sector: a cross-country empirical assessment. IAW Diskussionspapiere, 44.

Bond, S., R. (2002). Dynamic panel data models: a guide to micro data methods and practice. Portuguese Economic Journal, 1, 141-162.

Ercegovac, D., Jovin, S., \& Račić, Ž. (2018). The digital transformation of the banking sector in Serbia. In Proceeding from XXIII International Scientific Conference - SM2018 (480-488). Subotica, Republic of Serbia: Faculty of Economics in Subotica.

Ercegovac, D., Vlaović Begović, S., \& Jovin, S. (2019). The analysis of the key indicators of the Republic of Serbia banking sector. Anali Ekonomskog fakulteta u Subotici, 55(41), 81-94.

Hada, T., Bărbuță-Mișu, N., Cristina Iuga, I., \& Wainberg, D. (2020). Macroeconomic Determinants of Non-performing Loans of Romanian Banks. Sustainability, 12(18), 7533.

Hamid Mahmood, H., Waheed, A., \& Khalid, S. (2014). Role of Macroeconomic Indicators in Banking Crisis. Academic Research International, 5(2), 205.

Kiymaz, H. (2004). Cross-border acquisitions of US financial institutions: Impact of macroeconomic factors. Journal of Banking \& Finance, 28(6), 1413-1439.

Kripfganz, S. (2021). XTDPDGMM: Stata module to perform generalized method of moments estimation of linear dynamic panel data models. EconPapers, Economics at your fingers, available at: https://econpapers.repec.org/software/bocbocode/s458395.htm 
Lucchetta, M. (2007). What Do Data Say About Monetary Policy, Bank Liquidity and Bank Risk Taking? Economic Notes, 36(2), 189-203.

Milić, D., \& Jovin, S. (2017). The banking sector liquidity as a foundation for introducing innovations in business. In Innovation, Ict and Education for the Next Generation (223-235). Novi Sad, Repubic of Serbia: Faculty of Economics and Engineering Management.

Milišić, N., \& Račić, Ž. (2019). Research of determinants of non-performing loans of the banking sector of Serbia. School of Business, 2/2019, 23-34.

Mitrović, R., Nestorović, M., \& Ljubić, M. (2016). Relationship between macroeconomic aggregates and bank performance. Megatrend revija, 13(1), 131-146.

Mohammad, S., Asutay, M., Dixon, R., \& Platonova, E. (2020). Liquidity risk exposure and its determinants in the banking sector: A comparative analysis between Islamic, conventional and hybrid banks. Journal of International Financial Markets, Institutions and Money, 66, 101196.

Newbold, P., Carlson, W. L., \& Thorne, B. (2010). Statistika za poslovanje $i$ ekonomiju. Zagreb: MATE.

Olufemi, A. A., \& Muazu, I. (2020). On the macroeconomic determinants of financial institutions development in sub-Saharan Africa. International Review of Economics, 67, 69-85.

Račić, Ž. (2014). Uticaj osnovnih makroekonomskih pokazatelja na likvidnost bankarskog sektora Srbije. School of Business, 2/2014, 67-76.

Račić, Ž., Stanišić, N., \& Račić, M. (2014). A Comparative Analysis of the Determinants of Interest Rate Risk Using the Example of Banks from Developed and Developing Financial Markets. Engineering Economics, 25(4), 395-400.

Somoye, R., O., C., \& Ilo, B., M. (2009). The Impact of Macroeconomic Instability on the Banking Sector Lending Behaviour in Nigeria. Journal of Money, Investment and Banking, 7.

Sufian, F., \& Habibullah, M. S. (2009). Bank specific and macroeconomic determinants of bank profitability: Empirical evidence from the China banking sector. Frontiers of Economics in China, 2, 274-291.

Swamy, V. (2012) Impact of Macroeconomic and Endogenous Factors on Non Performing Bank Assets. Available at SSRN 2060753. 
47 | The impact of macroeconomic indicators on the business performance of financial institutions in the Republic of Serbia: Panel data analysis

Trenca, I., Petria, N., \& Corovei, E., A. (2015). Impact of Macroeconomic Variables upon the Banking System Liquidity. Procedia Economics and Finance, 32. 1170-1177.

Živkov, D., Poparić, S., \& Ilić, M. (2020). The effect of macro factors on bank credit activity in the Republic of Serbia. School of Business 1/2020, 3954.

Delivered: 20.07.2021.

Accepted: 29.11.2021. 